\title{
Hubungan Pendidikan dan Pekerjaan dengan Kecemasan pada Gay, Transgender, LSL Bandar Lampung
}

\author{
Resati Nando Panonsih ${ }^{1 *}$, Ade Utia Detty ${ }^{2}$, Arif Effendii ${ }^{3}$, Rika Arianofela ${ }^{4}$ \\ ${ }^{1)}$ Departemen Dermatologi dan Venereologi RS Pertamina Bintang Amin,dr_r3sati@yahoo.com \\ ${ }^{2)}$ Departemen Imunologi Fakultas Kedokteran Universitas Malahayati, adeutiadetty@gmail.com \\ ${ }^{3}$ Departemen Dermatologi dan Venereologi Rumah Sakit Abdul Moeloek, arif.effendi62@yahoo.com \\ ${ }^{4)}$ Program Studi Kedokteran Fakultas Kedokteran Universitas Malahayati, rikanovelaa@gmail.com
}

\begin{abstract}
ABSTRAK
Gay, Transgender, dan LSL adalah individu yang mengalami hambatan dalam kesehatannya. Kelompok ini rentan mengalami kecemasan dikarenakan banyak faktor yang mempengaruhinya, seperti dalam hal pendidikan dan pekerjaan. Dari penelitian yang sudah dilakukan didapatkan 277 subjek penelitian yang merupakan kelompok gay ditemukan 44\% memiliki gangguan kecemasan. Hal ini sangatlah penting karena semakin tinggi tingkat kecemasan seseorang akan sangat berpengaruh pada kondisi fisik dan psikis. Tujuan: Mengetahui Hubungan Pendidikan dan Pekerjaan dengan Tingkat Kecemasan pada Gay, Transgender, dan LSL di Bandar Lampung. Metode: Penelitian survei analitik dengan pendekatan cross-sectional. Jenis data yang diperoleh yaitu data primer. Cara pengumpulan data melalui kuesioner yang dibagikan kepada responden untuk mendapatkan jawaban pertanyaan. Penelitian ini dilakukan selama bulan November 2019. Pada penelitian ini sampel yang diambil meliputi seluruh anggota organisasi Gaya Lentera Muda dengan teknik total sampling. Hasil : Diketahui dari hasil penelitian menunjukkan sebagian besar resonden (gay, transgender, dan LSL) memiliki pendidikan menengah (SMA) sebanyak 19 responden (54,3\%), sebagian besar responden yang bekerja sebanyak 18 responden (51,4\%), dan pada responden yang memiliki tingkat pendidikan menengah sebagian besar mengalami kecemasan ringan sebanyak 7 responden (36,8\%) dan pada responden yang bekerja sebagian besar mengalami kecemasan ringan sebanyak 9 responden (50\%). Kesimpulan: Hasil akhir menunjukkan bahwa terdapat hubungan antara pendidikan dan pekerjaan dengan tingkat kecemasan pada gay, transgender, dan LSL di Bandar Lampung 2019) (pvalue $=-0,547$ dan $p$-value $=-0,595)$. Semakin tinggi tingkat pendidikan dan seseorang tersebut memiliki status bekerja maka semakin ringan tingkat kecemasan seseorang tersebut.
\end{abstract}

Kata kunci: Pendidikan, Pekerjaan, Kecemasan, Gay, Transgender

\begin{abstract}
Gay, Transgender, and MSM are group that experiencing detention in their health. This group susceptive of anxiety due to negative response from their environment especially from education and occupation. From the other research, showed that 44\% from 277 gay having anxiety disorders. This condition becomes very impotant because the higher of anxiety will impact to their physical and physicological condition.Objective: To determine the relationship between education and occupation with levels of anxiety to the Gay, Transgender, and MSM in Bandar Lampung 2019. Methods: The types of research is an analytic survey with cross-sectional approach. The type of data obtained are primary data. The method of collecting data is by given quesionnaire to get answer from subjects. This research was conducted during November 2019. In this research, the samples taken included all member of Gaya Lentera Muda organization of 35 subjects by total sampling technique. Results: It is known from the results of this research that the subjects (gay, transgender, and msm) mostly have middle of 19 subjects (54,3\%), mostly have an occupation of 18 subjects (51,4\%), and the subjects with middle education have mild anxiety of 7 subjects $(36,8 \%)$ and the subjects with an occupation mostly have mild anxiety of 9 subjects $(50,0 \%)$. Conclusion: The final results showed that there is a meaningful relationship between education and occupation with levels of anxiety to gay, transgender, and MSM in Bandar Lampung 2019 (p-value =-0,547 and p-value =-0,595). Higher the levels of education and if the person has an occupation, levels of anxiety will higher.
\end{abstract}

Keywords: Education, Job, Anxiety, Gay, Transgender

*Korespondensi Author :Resati Nando Panonsih, Departemen Dermatologi dan Venereologi Rumah Sakit Pertamina Bintang Amin,dr_r3sati@yahoo.com, Telp.081227766689 


\section{PENDAHULUAN}

Fenomena gay, transgender, dan LSL (Lelaki Seks Lelaki) menjadi isu yang banyak diperbincangkan ditengah masyarakat Indonesia. Gay adalah laki-laki yang mencintai atau merasakan rangasangan seksual dengan sesama laki-laki, gay ini memperjelas atau menunjukan pada perilaku homoseksual. Transgender merupakan ketidaksamaan dari identitas gender yang diberikan kepada orang tersebut dengan jenis kelaminnya. ${ }^{1}$ LSL (Lelaki Seks Lelaki) secara luas diartikan sebagai laki-laki yang berhubungan seksual dengan laki- laki, tanpa memandang orientasi seksualnya atau identitas gender. ${ }^{2}$

Kecemasan merupakan suatu keadaan yang mempengaruhi pikiran, persepsi, dan pembelajaran. Perdebatan terhadap kelompok gay, transgender, dan LSL membuahkan sikap negatif dari lingkungan sosial. Sikap masyarakat yang sedemikian negatif menimbulkan beragam perlakuan yang diterima oleh kelompok gay, transgender, dan LSL mulai dari kecaman, dibuang dari lingkungan sosial, dihina, dan diskriminasi terutama dalam hal pekerjaan dan pendidikan. Perlakuan yang demikian menjadi sumber stress bagi kelompok gay, transgender, dan LSL sehingga mereka mendapatkan masalah psikologis seperti gangguan kecemasan (anxiety disoders). ${ }^{3}$

Rendahnya tingkat kesehatan mental yang dimiliki oleh kelompok gay, transgender, LSL dapat diidentifikasi dari beragam masalah psikologis. Masalah yang mereka alami seperti gangguan kecemasan (anxiety disorders), depresi, gangguan mood (mood disorder), serangan panik (panic attack). Penjelasan diatas diperkuat oleh hasil penelitian King (2003), yakni dari 277 subjek penelitiannya yang merupakan kelompok gay ditemukan 44\% memiliki gangguan kecemasan (anxiety disorder). ${ }^{4}$

Para ahli dan PBB mengatakan jumlah kelompok gay, transgender, dan LSL jauh lebih banyak, yakni tiga juta jiwa pada 2011. Pada tahun 2009 populasi gay mencapai sekitar 800 ribu jiwa. ${ }^{1}$ Berdasarkan estimasi data Kemenkes pada 2012, terdapat 1.095.970 LSL (Lelaki Seks dengan Lelaki) baik yang tampak maupun tidak. Jumlah Transgender (Waria) pada tahun 2010 di 33 provinsi di Indonesia sebanyak 31.179 jiwa. $^{5}$ Gay, Transgender, dan LSL (Lelaki Seks Lelaki) tergabung dalam sebuah organisasi Gaylam (Gaya Lentera Muda) di Bandar Lampung. Dari hasil presurvey yang dilakukan pada hari Jumat, 4 Oktober 2019 didapatkan data pengurus organisasi dan anggota Gaylam sebanyak 30-35 orang.

Perdebatan terhadap kelompok gay, transgender, dan LSL membuahkan sikap negatif dari lingkungan sosial. Sikap masyarakat yang sedemikian negatif menimbulkan beragam perlakuan yang diterima oleh kelompok gay, transgender, dan LSL mulai dari kecaman, dibuang dari lingkungan sosial, dihina, dan diskriminasi terutama dalam hal pekerjaan. Diskriminasi terhadap kelompok gay, transgender, dan LSL di tempat kerja belum mendapatkan perhatian yang berarti. Belum ada undang-undang anti diskriminasi maupun kebijakan atau pernyataan yang jelas sehubungan dengan orang-orang gay, transgender, dan LSL di tempat kerja serta kurangnya pendidikan akan berdampak buruk pada rasa percaya diri kelompok gay, transgender, dan LSL. ${ }^{6}$ Perlakuan yang demikian menjadi sumber stress bagi kelompok gay, transgender, dan LSL sehingga mereka mendapatkan masalah psikologis seperti gangguan kecemasan (anxiety disoders). Kecemasan dengan berbagai macam gejala dan tingkatannya dapat mengganggu konsentrasi individu dalam bekerja dan dapat membuat individu kesulitan untuk berinteraksi dengan lingkungan sosialnya. Tingginya tingkat kecemasan akan menyebabkan kehidupan seseorang yang sebelumnya normal menjadi sulit. ${ }^{7} \mathrm{Hal}$ ini sangatlah penting karena tingginya tingkat kecemasan $\mathrm{Hal}$ ini sangatlah penting karena semakin tinggi tingkat kecemasan seseorang akan sangat berpengaruh pada kondisi fisik dan psikis.

\section{METODOLOGI}

Penelitian ini menggunakan metode survei analitik observasional yang bersifat 
kuantitatif, dengan menggunakan studi korelatif dan pendekatan cross sectional. Peneliti ingin mencari tahu hubungan pendidikan dan pekerjaan dengan tingkat kecemasan pada gay, transgender, dan LSL di Bandar Lampung. Teknik sampel yang digunakan yaitu total sampling. Penelitian ini dilaksanakan pada bulan November 2019.

Populasi dalam penelitian ini adalah seluruh kelompok gay, transgender, dan LSL yang termasuk dalam Organisasi Gaya Lentera Muda Bandar Lampung. Sampel yang diambil yaitu seluruh anggota organisasi yang berjumlah 35 orang dengan menggunakan kuesioner Hamilton Anxiety Rating Scale (HARS) untuk mengukur tingkat kecemasan seseorang. Kuesioner Hamilton Anxiety Rating Scale (HARS) terdapat 14 kelompok gejala yang masing-masing kelompok dirinci lagi dengan gejala-gejala yang lebih spesifik meliputi perasaan cemas, ketegangan, ketakutan, gangguan tidur, gangguan kecerdasan, perasaan depresi, gejala somatik, gejala sensorik, gejala kardiovaskuler, gejala pernapasan, gejala gastrointestinal, gejala urogenital, gejala otonom, sikap dan tingkah laku. Masing-masing kelompok gejala diberikan dengan penilaian angka (skor) 0-4, yang artinya tidak ada gejala diberikan skor 0 , gejala ringan diberikan skor 1 , gejala sedang diberikan skor 2, gejala berat diberikan skor 3, gejala berat sekali diberikan skor 4. Masing- masing nilai angka (skor) dari 14 kelompok gejala tersebut dijumlahkan dan dari hasil penjumlahan tersebut dapat diketahui derajat kecemasan seseorang. ${ }^{8}$

Pengambilan data dengan menggunakan kuesioner dilaksanakan di rumah kesekretariatan organisasi Gaya Lentera Muda yang didampingi langsung oleh peneliti. Kelompok gay, transgender, dan LSL diberikan kuesioner dan menjawab pertanyaan yang terdapat dalam kuesioner tersebut. Hasil penelitian ini akan diakumulasikan dan dikategorikan apakah termasuk normal (tidak ada kecemasan), kecemasan ringan, sedang, berat. Teknik analisis data pada penelitian ini menggunakan uji univariat dan bivariat. Uji univariat digunakan untuk menentukan distribusi tingkat pendidikan, status pekerjaan, dan tingkat kecemasan sedangkan uji bivariat dilakukan dengan uji statistik Korelasi Spearman untuk menentukan apakah terdapat hubungan antara pendidikan dan pekerjaan dengan tingkat kecemasan pada Gay, Transgender, dan LSL.

\section{HASIL DAN PEMBAHASAN Hasil Analisis Univariat}

Tabel 1. Distribusi Tingkat Pendidikan pada Gay, Transgender, dan LSL

\begin{tabular}{lcc}
\hline Tingkat Pendidikan & Frekuensi & $\begin{array}{c}\text { Persentase } \\
(\%)\end{array}$ \\
\hline Dasar & 11 & 31,4 \\
Menengah & 19 & 54,3 \\
Tinggi & 5 & 14,3 \\
\hline \multicolumn{1}{c}{ Total } & 35 & 100 \\
\hline
\end{tabular}

Pada tabel 1 menunjukkan bahwa distribusi tingkat pendidikan pada gay, transgender, dan LSL. Didapatkan responden yang memiliki pendidikan menengah sebanyak 19 responden (54,3\%), pendidikan dasar sebanyak 11 responden $(31,4 \%)$, dan pendidikan tinggi sebanyak 5 responden (14,3\%). Jumlah responden pada penelitian ini sebanyak 35 responden $(100 \%)$.

Tabel 2. Distribusi Status Pekerjaan pada Gay, Transgender, dan LSL

\begin{tabular}{|c|c|c|}
\hline Status Pekerjaan & Frekuensi & $\begin{array}{c}\text { Persentase } \\
(\%)\end{array}$ \\
\hline Tidak Bekerja & 17 & 48,6 \\
\hline Bekerja & 18 & 51,4 \\
\hline Total & 35 & 100 \\
\hline
\end{tabular}
distribusi status pekerjaan pada gay, transgender, dan LSL. Didapatkan kelompok responden yang bekerja sebanyak 18 responden $(51,4 \%)$ dan responden dengan status pekerjaan tidak bekerja sebanyak 17 responden $(48,6 \%)$. Jumlah responden pada penelitian ini sebanyak 35 responden $(100 \%$

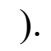


Tabel 3. Distribusi Jenis Pekerjaan pada Gay, Transgender, dan LSL

\begin{tabular}{lcc}
\multicolumn{1}{c}{ Jenis Pekerjaan } & Frekuensi & Persentase \\
\hline ASN (Aparatur Sipil & 2 & 11,1 \\
Negara) & & \\
Wiraswasta & 11 & 61,1 \\
Pegawai Swasta & 5 & 27,8 \\
\hline \multicolumn{1}{c}{ Total } & 18 & 100 \\
\hline
\end{tabular}

Pada tabel 3 menunjukkan bahwa distribusi jenis pekerjaan pada gay, transgender, dan LSL. Jenis pekerjaan yang didapat meliputi pekerjaan wiraswasta sebanyak 11 responden $(31,4 \%)$, pegawai swasta sebanyak 5 responden $(14,3 \%)$, ASN (Aparatur Sipil Negara) sebanyak 2 responden $(5,7 \%)$. Jumlah responden yang bekerja sebanyak 18 responden $(51,4 \%)$.

Tabel 4. Distribusi Tingkat Kecemasan pada Gay, Transgender, dan LSL

\begin{tabular}{ccc}
\hline $\begin{array}{c}\text { Tingkat } \\
\text { Kecemasan }\end{array}$ & Frekuensi & $\begin{array}{c}\text { Persentase } \\
(\%)\end{array}$ \\
\hline $\begin{array}{c}\text { Tidak Ada } \\
\text { Kecemasan }\end{array}$ & 4 & 11,4 \\
$\begin{array}{c}\text { Kecemasan } \\
\text { Ringan }\end{array}$ & 11 & 31,4 \\
$\begin{array}{c}\text { Kecemasan } \\
\text { Sedang }\end{array}$ & 10 & 28,6 \\
\hline
\end{tabular}

\begin{tabular}{ccc}
\hline $\begin{array}{c}\text { Tingkat } \\
\text { Kecemasan }\end{array}$ & Frekuensi & $\begin{array}{c}\text { Persentase } \\
(\%)\end{array}$ \\
\hline Kecemasan Berat & 10 & 28,6 \\
\hline Total & 35 & 100 \\
\hline
\end{tabular}

Pada tabel 4 menunjukkan bahwa distribusi tingkat kecemasan pada gay, transgender, dan LSL. Didapatkan responden yang mengalami kecemasan ringan sebanyak 11 responden $(31,4 \%)$, kecemasan berat didapatkan sebanyak 10 responden $(28,6 \%)$, kecemasan sedang sebanyak 10 responden $(28,6 \%)$, dan yang tidak mengalami kecemasan sebanyak 4 responden $(11,4 \%)$. Jumlah responden pada penelitian ini sebanyak 35 responden $(100 \%)$.

\section{Hasil Analisis Bivariat}

Analisis bivariat dilakukan untuk mengetahui apakah terdapat hubungan yang bermakna antara dua variabel. Dalam hal ini untuk mengetahui apakah terdapat hubungan antara pendidikan dan pekerjaan dengan tingkat kecemasan pada gay, transgender, dan LSL di Bandar Lampung 2019. Uji statistik yang akan digunakan pada penelitian ini Uji korelasi Spearman karena data tidak terdistribusi normal.

Tabel 5. Hubungan Tingkat Pendidikan dengan Tingkat Kecemasan pada Gay, Transgender, dan LSL

\begin{tabular}{|c|c|c|c|c|c|c|c|c|c|c|c|c|c|}
\hline & & \multicolumn{8}{|c|}{ Tingkat Kecemasan } & \multirow{2}{*}{\multicolumn{2}{|c|}{ Total }} & \multirow{2}{*}{$\mathrm{P}$} & \multirow{2}{*}{$\mathrm{r}$} \\
\hline & & \multicolumn{2}{|c|}{$\begin{array}{c}\text { Tidak Ada } \\
\text { Kecemasan }\end{array}$} & \multicolumn{2}{|c|}{ Ringan } & \multicolumn{2}{|c|}{ Sedang } & \multicolumn{2}{|c|}{ Berat } & & & & \\
\hline & & $\mathrm{N}$ & $\%$ & $\mathrm{~N}$ & $\%$ & $\mathrm{~N}$ & $\%$ & $\mathrm{~N}$ & $\%$ & $\mathrm{~N}$ & $\%$ & & \\
\hline & Dasar & 0 & 0 & 1 & 9,1 & 2 & 18,2 & 8 & 72,7 & 11 & 31,4 & & \\
\hline \multirow[t]{3}{*}{$\begin{array}{c}\text { Tingkat } \\
\text { Pendidikan }\end{array}$} & Menengah & 4 & 21,1 & 7 & 36,8 & 6 & 31,6 & 2 & 10,5 & 19 & 54,3 & 0,001 & $-0,547$ \\
\hline & Tinggi & 0 & 0 & 3 & 60,0 & 2 & 40,0 & 0 & 0 & 5 & 14,3 & & \\
\hline & Total & 4 & 11,4 & 11 & 31,4 & 10 & 28,6 & 10 & 28,6 & 35 & 100 & & \\
\hline
\end{tabular}

Pada tabel 5 menunjukkan bahwa hasil analisis uji korelasi spearman dengan tingkat kesalahan $5 \%$ menggunakan SPSS 20.0 didapatkan nilai $p=0,001$ dimana nilai $p \leq 0,05$ menunjukkan Ho ditolak. Artinya, secara statistik terdapat hubungan yang bermakna 
antara tingkat pendidikan dengan tingkat kecemasan pada gay, transgender, dan LSL di Bandar Lampung 2019. Nilai koefisien korelasi sebesar -0,547 menunjukkan kekuatan korelasi sedang dan bernilai negatif. Pada tabulasi silang dapat dilihat bahwa responden dengan pendidikan dasar mengalami kecemasan berat sebanyak 8 responden $(72,7 \%)$, kecemasan sedang sebanyak 2 responden $(18,2 \%)$, dan yang mengalami kecemasan ringan sebanyak 1 responden (9,1\%). Responden dengan pendidikan menengah mengalami kecemasan ringan sebanyak 7 responden $(36,8 \%)$, kecemasan sedang sebanyak 6 responden $(31,6 \%)$, tidak mengalami kecemasan sebanyak 4 responden $(21,1 \%)$ dan kecemasan berat sebanyak 2 responden (10,5\%). Responden dengan pendidikan tinggi mengalami kecemasan ringan sebanyak 3 responden $(60,0 \%)$ dan kecemasan sedang sebanyak 2 responden $(40,0 \%)$.

Hasil penelitian ini sesuai dengan penelitian yang dilakukan oleh Aman dan
Ambarini (2019) dimana dari hasil penelitian tersebut didapatkan seluruh responden (gay) memiliki kecemasan sosial yang dibuktikan dengan hasil wawancara pada responden yaitu adanya pengalaman traumatis dengan teman sebaya, kurang kehangatan emosional serta orangtua yang over protektif, dan penolakan di masa kanak-kanak seperti mengalami bullying ketika menempuh pendidikan di Sekolah Dasar. Hal ini membuat para gay memiliki ketakutan dan cenderung melakukan penghindaran sosial sehingga banyak dari mereka yang tidak menyelesaikan pendidikan mereka sampai ke tahap tingkat pendidikan tinggi. ${ }^{9}$ Seseorang yang mempunyai pendidikan lebih tinggi akan memberikan respon yang lebih rasional dibandingkan mereka yang tidak berpendidikan tidak mampu menghadapi suatu tantangan dengan rasional. Diharapkan tingkat pendidikan yang tinggi pada seseorang akan membentuk pola yang adaptif terhadap kecemasan, karena memiliki pola koping terhadap sesuatu yang lebih baik. ${ }^{10}$

Tabel 6. Hubungan Status Pekerjaan dengan Tingkat Kecemasan pada Gay, Transgender, dan LSL

Tingkat Kecemasan

\begin{tabular}{|c|c|c|c|c|c|c|c|c|c|c|c|c|c|}
\hline & & \multicolumn{2}{|c|}{$\begin{array}{l}\text { Tidak Ada } \\
\text { Kecemasan }\end{array}$} & \multicolumn{2}{|c|}{ Ringan } & \multicolumn{2}{|c|}{ Sedang } & \multicolumn{2}{|c|}{ Berat } & \multicolumn{2}{|c|}{ Total } & \multirow[t]{2}{*}{$\mathrm{P}$} & \multirow[t]{2}{*}{$r$} \\
\hline & & $\mathrm{N}$ & $\%$ & $\mathrm{~N}$ & $\%$ & $\mathrm{~N}$ & $\%$ & $\mathrm{~N}$ & $\%$ & $\mathrm{~N}$ & $\%$ & & \\
\hline \multirow{3}{*}{$\begin{array}{c}\text { Status } \\
\text { Pekerjaan }\end{array}$} & $\begin{array}{c}\text { Tidak } \\
\text { Bekerja }\end{array}$ & 1 & 5,9 & 3 & 17,6 & 3 & 17,6 & 10 & 58,8 & 17 & 48,6 & \multirow{3}{*}{0,000} & \multirow{3}{*}{$-0,595$} \\
\hline & Bekerja & 4 & 22,2 & 9 & 50,0 & 5 & 27,8 & 0 & 0 & 18 & 51,4 & & \\
\hline & Total & 4 & 11,4 & 11 & 31,4 & 10 & 28,6 & 10 & 28,6 & 35 & 100 & & \\
\hline
\end{tabular}

Berdasarkan tabel 6 menunjukkan bahwa hasil analisis uji korelasi spearman dengan tingkat kesalahan $5 \%$ menggunakan SPSS 20.0 didapatkan nilai $p=0,000$ dimana nilai $p \leq 0,05$ menunjukkan Ho ditolak. Artinya, secara statistik terdapat hubungan yang bermakna antara status pekerjaan dengan tingkat kecemasan pada gay, transgender, dan LSL di Bandar Lampung 2019. Nilai koefisien korelasi sebesar -0,595 menunjukkan kekuatan korelasi sedang dan bernilai negatif. Pada tabulasi silang dapat dilihat bahwa responden yang tidak bekerja mengalami kecemasan berat sebanyak 10 responden $(58,8 \%)$, kecemasan sedang sebanyak 3 responden $(17,6 \%)$, kecemasan ringan sebanyak 3 responden (17,6\%), dan yang tidak mengalami kecemasan sebanyak 1 responden $(5,9 \%)$. Responden yang bekerja mengalami tingkat kecemasan ringan sebanyak 9 responden $(50,0 \%)$, kecemasan sedang 
sebanyak 5 responden $(27,8 \%)$, dan yang tidak mengalami kecemasan sebanyak 4 responden $(22,2 \%)$.

Hasil penelitian ini sesuai dengan penelitian yang dilakukan oleh Alfaris (2018) dimana pada hasil penelitian tersebut didapatkan responden penelitian (transgender) mengalami kecemasan dalam hal pekerjaan, tidak sedikit dari mereka yang tidak bekerja atau melakukan pekerjaan negatif dan melanggar hukum seperti berprofesi sebagai pekerja seks komersil (PSK). Kecemasan yang dialami para transgender itu adalah keinginan mereka untuk dianggap ada dalam eksistensinya terutama dalam hal mencari pekerjaan yang memang kecil kemungkinan mereka dapat diterima bekerja seperti orang normal pada umumnya. Disisi lain pekerjaan memegang peranan penting dalam kehidupan, yaitu dalam hal mencukupi kebutuhan hidup secara primer dan sekunder. ${ }^{11}$ Seseorang yang bekerja akan lebih memiliki produktivitas diri dan menambah wawasan dengan berinteraksi pada orang lain sehingga akan mengurangi tingkat kecemasan pada seseorang tersebut. Dapat disimpulkan bahwa seseorang yang bekerja maka akan semakin ringan tingkat kecemasannya dibanding seseorang yang tidak bekerja.

Menurut Oetomo dan Suvianita (2014), adanya diskriminasi terhadap individu gay, transgender, dan LSL di tempat kerja belum mendapatkan perhatian yang berarti. Belum ada undang-undang anti diskriminasi maupun kebijakan atau pernyataan yang jelas sehubungan dengan orang-orang gay, transgender, dan LSL di tempat kerja. Kelompok gay banyak mengalami kasus bullying pada masa pendidikan mereka, hal itulah yang mengakibatkan sedikit dari mereka yang memiliki pendidikan tinggi. Sebagian besar diskriminasi diarahkan pada kelompok transgender yang juga mengalami masalah dengan KTP tidak tercantum gender pilihan mereka. Masalah- masalah ini dapat membawa dampak lanjutan seperti halnya masalah psikologis terutama gangguan kecemasan untuk mendapatkan tempat tinggal, pekerjaan tetap. ${ }^{6}$

\section{SIMPULAN DAN SARAN}

Berdasarkan hasil penelitian dan pembahasan tentang hubungan pendidikan dan pekerjaan dengan tingkat kecemasan pada gay, transgender, dan LSL di Bandar Lampung 2019, maka dapat disimpulkan bahwa :

1. Diketahui sebagian besar tingkat pendidikan kelompok gay, transgender, dan LSL adalah Pendidikan Menengah (SMA) sebanyak 19 responden $(54,3 \%)$

2. Diketahui sebagian besar status pekerjaan pada gay, transgender, dan LSL adalah kelompok yang bekerja sebanyak 18 responden $(51,4 \%)$

3. Diketahui sebagian besar distribusi tingkat kecemasan pada gay, transgender, dan LSL di Bandar Lampung 2019 adalah kelompok yang mengalami kecemasan ringan sebanyak 11 responden $(31,4 \%)$

4. Diketahui terdapat hubungan yang bermakna antara tingkat pendidikan dengan tingkat kecemasan pekerjaan pada gay, transgender, dan LSL di Bandar Lampung 2019 dengan nilai $p$ value $=0,001 \quad(p \leq 0,05)$. Dan didapatkan nilai korelasi $r=-0,547$ yang artinya kekuatan korelasi pada penelitian ini adalah korelasi sedang dan mempunyai arah korelasi negatif. Dapat disimpulkan bahwa semakin tinggi tingkat pendidikan makan semakin ringan tingkat kecemasan pada seseorang.

5. Diketahui terdapat hubungan yang bermakna antara status pekerjaan dengan tingkat kecemasan pekerjaan pada gay, transgender, dan LSL di Bandar Lampung 2019 dengan nilai $p$ value $=0,000 \quad(p \leq 0,05)$. Dan didapatkan nilai korelasi $r=-0,595$ yang artinya kekuatan korelasi pada penelitian ini adalah korelasi sedang dan mempunyai arah korelasi negatif. Dapat disimpulkan bahwa seseorang yang bekerja maka akan semakin ringan tingkat kecemasannya dibanding seseorang yang tidak bekerja.

Hasil penelitian ini diharapkan dapat dijadikan acuan hubungan antara pendidikan dan pekerjaan dengan tingkat kecemasan pada gay, transgender, dan LSL. Diharapkan pula pada 
peneliti selanjutnya dapat melakukan penelitian dengan jumlah sampel yang lebih banyak.

\section{UCAPAN TERIMA KASIH}

Peneliti mengucapkan terima kasih kepada Tuhan Yang Maha Esa yang telah memberikan rahmat dan pertolongannya sehingga penelitian ini dapat berjalan dengan lancar. Peneliti juga mengucapkan terima kasih kepada semua pihak yang berperan dalam pelaksanaan penelitian ini, terutama kepada Pengurus dan Anggota Organisasi Gaya Lentera Muda Bandar Lampung.

\section{REFERENSI}

1. KemenSos RI. Meluasnya LGBT (Lesbian, gay, biseksual, dan Transgender) Akibat Lemahnya Social Control Masyarakat. Dalam Kementrian Sosial Republik Indonesia; 2016 [dikutip 7 September 2019]. Tersedia pada: http://puspensos.kemsos.go.id/home/breng/324.

2. Kemenkes RI. Pedoman Nasional Infeksi Menular Seksual. Jakarta: Kementrian Kesehatan Republik Indonesia; 2016.

3. Sadock B, Sadock V. Kaplan \& Sadock Buku Ajar Pskiatri Klinis. 2 ed. Jakarta: EGC; 2015.

4. Tambunan D. Perbedaan Kesehatan Mental pada Gay Ditinjau Dari Perilaku Religius [Skripsi]. Medan: Fakultas Kedokteran Universitas Sumatera Utara; 2010.

5. KemenSos RI. Kementrian Sosial Dalam Rangka Pembangunan Kesejahteraan Sosial. Jakarta: Badan Pendidikan dan Penelitian Kesejahteraan Sosial; 2012.

6. Oetomo D, Suvianita K. Tinjauan dan Analisa Partisipatif tentang Lingkungan Hukum dan Sosial bagi Orang dan Masyarakat Madani Lesbian, Gay, Biseksual, dan Transgender (LGBT). Jakarta: UNSAID\&UNDP; 2014.

7. Vitasari P, Wahab MNA, Herawan T. Re-test of State Trait Anxiety Inventory (STAI) among Engineering Students in Malaysia: Reliability and Validity tests. Procedia Social and Behavioral Sciences. 2011;15:3844.

8. Hawari D. Manajemen Stress Cemas dan Depresi. Jakarta: Fakultas Kedokteran Indonesia; 2011.

9. Aman IS, Ambarini TK. Gambaran Kecemasan Sosial pada Gay di Surabaya. Jurnal Psikologi dan Kesehatan Mental. 2019;8(1):5-9.

10. Notoatmodjo S. Ilmu Perilaku Kesehatan. Jakarta: Rineka Cipta; 2014.
11. Alfaris MR. Eksistensi Diri Waria Dalam Kehidupan Sosial di Tengah Masyarakat Kota (Fenomena Tentang Eksistensi Diri Waria Urbanisasi di Kota Malang. Jurnal Hukum. 2018;1(1):101-105. 